\title{
CLUSTERING THE TECHNICAL CAPABILITY IN THE BRAZILIAN AERONAUTICAL MAINTENANCE INDUSTRY
}

Marcio Cardoso Machado Professor of Production Department, Mechanical Engineering Division, Aeronautical Institute of Technology, São Paulo, Brazil Email: cardoso@ita.br.

Ligia Maria Soto Urbina Professor of Production Department, Mechanical Engineering Division, Aeronautical Institute of Technology, São Paulo, Brazil Email: ligia@ita.br.

Rodrigo Arnaldo Scarpel Professor of Production Department, Mechanical Engineering Division, Aeronautical Institute of Technology, São Paulo, Brazil Email: rodrigo@ita.br.

Acknowledgment Coordenação de Aperfeiçoamento de Pessoal de Nível Superior CAPES

Submission: 24/06/2013 Accept: 10/07/2013

\section{Abstract}

In the sectors where equipment requiring services of maintenance are technologically complex and advanced, such as in the air transportation, knowing and managing the technical capability of the enterprises of the sector can be a good way maximizing the efforts of training. This paper attempts to present a process of technical capability clustering for the aeronautical maintenance industry, in order to provide a usable overview of the sector competences. The findings present a unique insight into the understanding of competences clustering that may be used across different industries.

Keywords: aeronautical maintenance; technical capability; clustering process. 


\section{INTRODUCTION}

Aircraft maintenance is a highly regulated, safety critical, complex and competitive industry (BRUECKER, et al. 2012). and resulting activities are an essential part of the continued airworthiness, aiming to provide, both, in civilian and military areas, the total service condition for the aircraft at the time that an operator request, with the expected quality and minimal cost (KNOTTS, 1999). This service is extremely important to support the air transportation in countries like Brazil, which are characterized by having a large territory with strong civilian and military air traffic, linking the various regions of the country. Regarding this subject, a review of relevant academic literature showed that this subject has received little attention in the academic community, opening up opportunities for research. In fact, it is possible to note that several studies focus on issues relating to the conduct of management and technical-economic activities, at sector or industry level.

Thus, Phillips et al. (2010) studies review current aircraft maintenance practices, while Machado et al. (2009) make a preliminary analysis of the managerial capability of Brazilian maintenance companies for aeronautical equipment, using as reference an European maintenance process model (EURSPACE, 2003). Also, Durand (2008) studies relevant aspects of aircraft maintenance, related to the expected changes in the American Air Force maintenance organizational structure, as a result of implementing a resource planning system (Expeditionary Combat Support System).

Some of the papers found in the literature review explore the aircraft maintenance from other perspectives that seek to improve the efficiency of the sector. As an example, Rodrigues et al. (2010) study the costs perspective, while Papakostas et al. (2010) focus their efforts in the selection of maintenance strategies. Vilela et al. (2010) examines the relationship of accidents with aircraft maintenance and operational safety recommendations. Other authors focus on classical maintenance subjects like scheduling aircraft maintenance personnel (DE BRUECKER; VAN DEN BERGH; BELIEN; DEMEULEMEESTER, 2012); estimate the probability of failure for complex systems (JACOB; DUBOIS; CARDOSO; CEBERIO; KREINOVICH, 2011), maintenance planning (SAMARANAYAKE, 2006; SAMARANAYAKE, et al., 2007) and human risk factors in aircraft maintenance technicians (CHANG; WANG, 2010). 
INDEPENDENT JOURNAL OF MANAGEMENT \& PRODUCTION (IJM\&P)

http://www.ijmp.jor.br

v. 4, n. 2, July - September 2013.

ISSN: 2236-269X

DOI: 10.14807/ijmp.v4i2.101

In this context, this paper aims to expand knowledge about the technical capability aircraft maintenance industry in Brazil exploring the information provided by Agência Nacional de Aviação Civil (ANAC), with the main goal of presenting a process of technical capability clustering for the aeronautical maintenance industry, in order to provide a usable overview of the sector competences.

More specifically, this paper begins with an exposition of the basic concepts of maintenance activity in general and aviation in particular. The following is an exploratory research carried out from secondary data in order to detect technical patterns of the aeronautical maintenance in the Brazilian regulatory context, which circumscribes and certifies the activities that companies have the technical competence to perform. Finally, it was possible to present a unique insight into the understanding of competences clustering.

\section{BASIC CONCEPTS OF MAINTENANCE ACTIVITY}

\subsection{The Maintenance Activity}

To achieve world class performance, companies are struggling efforts to improve quality and productivity and reduce costs (MISHRA et al., 2006). For several companies, some of these efforts should include an analysis of the maintenance function activities. An effective maintenance is essential for many operations. It is possible through that, to extend the product life cycle, improve the equipment availability and keep them in good conditions. On the other hand, maintenance neglect can lead to more frequent failures, equipment underutilization and the consequent delay in production schedules. In accordance with Niu, et al. (2010) and Muchiri, et al. (2011), maintenance, as a strategic function to support business, plays an important role in supporting the production function and its management. In fact, besides maintaining equipment functioning, maintenance management also supports the good performance or even implementation of production management techniques such as lean manufacturing, just-in-time and six-sigma. The effectiveness in the maintenance management depends on the appropriate deployment of resources such as replacement parts, tools, equipment or workforce. This feature imposes a strategic approach to the maintenance activities. To consider maintenance just as a tactical element in companies is a limited view. In fact, such function also has a strategic dimension with implications for the facilities project and maintenance 
DOI: 10.14807/ijmp.v4i2.101

programs, upgrading knowledge and skills of the workforce and deploying the work load and tools for the accomplishment of the various maintenance activities. The maintenance management becomes, therefore, an important element to be studied scientifically and that is what has happened. For Sherwin (2000), maintenance systems should be tailored to the nature of work that will be managed. In other words, in the steel industry, for example, will be established procedures for maintenance management that will differ from those one used in the aerospace industry.

\subsection{Technical capability in the Aeronautical Maintenance Context}

The aircraft maintenance can be divided into two activities that, despite being fully associated, possess different characteristics. The first activity is related to aircraft maintenance as single equipment, and the second activity concerns components maintenance that will serve as inputs to the first one. This distinction is necessary because the aircraft maintenance operations follow rules that go beyond the technical expertise necessary to perform maintenance activities.

\subsubsection{Maintenance Types}

Aircraft maintenance can also be classified as preventive maintenance (hard time and condition monitoring), corrective maintenance (corrective) or predictive maintenance (on condition) (KNOTTS, 1999).

- preventive maintenance - According to Soro, et al. (2010), preventive maintenance is the practice of replacing components or subsystems before they fail, usually with predetermined frequency (hard time) or due to inspection and test (condition monitoring). The goal is to maintain continuous operation of the system, in this case the aircraft;

- corrective maintenance - In accordance with Moayed and Shell (2009) this is one that occurs after the identification and diagnosis of a problem. During this diagnostic maintenance technicians have to identify the failed parties to implement their correct actions and repair;

- predictive maintenance - it takes into account the continuous monitoring of the operational limits of a given component or subsystem. If any tendency for the occurrence of a component or subsystem functional failure appears, it should be removed for maintenance. Some mechanisms for the implementation of 
INDEPENDENT JOURNAL OF MANAGEMENT \& PRODUCTION (IJM\&P)

http://www.ijmp.jor.br

v. 4, n. 2, July - September 2013.

ISSN: 2236-269X

DOI: 10.14807/ijmp.v4i2.101

predictive maintenance are the PDM (Product Data Management) and PHM (Product History Management).

\subsubsection{Regulatory Framework of Brazilian Aircraft Maintenance}

Any company that wants to be classified as an aircraft repair station, should submit a request to the (ANAC) for a certification, specifying which aircraft, engine, propeller, rotor, equipment or component, they will perform the maintenance service. Based on Brazilian Civil Aviation Regulation RBHA 145 (BRAZIL, 2005) it is evaluated the technical and organization qualifications of the company and if confirmed these qualifications, a Brazilian Repair Station Certificate (CHE) is issued to that company. It should also be noted that, airlines companies that possess RBHA 121 (Certification and Operation of Large Airplanes Domestic and Flag Operators) (BRAZIL, 2003a) or RBHA 135 (Certification and Operation of Small Airplanes and Helicopter Domestic and Flag Operators) (BRAZIL, 2003b) certification, do not need to certificate its repair stations according to RBHA 145, to perform services on its own fleet or, under contract, to another airline company also certified by those same RBHAs.

\section{TECHNICAL PATTERNS}

Certified companies from the RBHA 145 will be classified according to their competence. Thus, when applying for a certification, the company should specify to ANAC the equipment for which it intends to offer the maintenance service, so that if approved, it will be classify into one or more patterns and classes of maintenance. This classification prevents that the repair station offers services than they are not licensed to perform. Understanding how aircraft maintenance enterprises combine their certifications, can be an important way to provide a usable overview of the sector competences and an insight into the understanding of competences of this industry (BRAZIL, 2005).

\subsection{Certification Technical Domain}

The Brazilian Repair Station Certificates issued by the ANAC, refers to aircraft maintenance companies and they are based on patterns and classes as shown in Table 1. 
INDEPENDENT JOURNAL OF MANAGEMENT \& PRODUCTION (IJM\&P)

http://www.ijmp.jor.br

v. 4, n. 2, July - September 2013.

ISSN: 2236-269X

DOI: 10.14807/ijmp.v4i2.101

Table 1 - Aircraft Maintenance Companies Patters and Classes

\begin{tabular}{|c|c|}
\hline Pattern & Class \\
\hline $\begin{array}{l}\text { Pattern } \quad \text { C } \\
\text { Maintenance, } \\
\text { modifications and cells } \\
\text { repair. }\end{array}$ & $\begin{array}{l}\text { (C1) - Composite structure aircraft, with maximum approved takeoff weight } \\
\text { up to } 5670 \mathrm{~kg} \text { (aircraft) or } 2730 \mathrm{~kg} \text { (Helicopters) per aircraft model. } \\
\text { (C2)- Metal structure aircraft, with maximum approved takeoff weight up to } \\
5670 \mathrm{~kg} \text { (aircraft) or } 2730 \mathrm{~kg} \text { (Helicopters) per aircraft model. } \\
\text { (C3)- Composite structure aircraft, with maximum approved takeoff weight } \\
\text { over } 5670 \mathrm{~kg} \text { (aircraft) or } 2730 \mathrm{~kg} \text { (Helicopters) per aircraft model. } \\
\text { (C4)- Metal structure aircraft, with maximum approved takeoff weight over } \\
5670 \mathrm{~kg} \text { (aircraft) or } 2730 \mathrm{~kg} \text { (Helicopters) per aircraft model. }\end{array}$ \\
\hline $\begin{array}{l}\text { Pattern } \quad \text { - } \\
\text { Maintenance, } \\
\text { modifications and } \\
\text { aircraft engines repair. }\end{array}$ & $\begin{array}{l}\text { (D1) - Conventional engines with up to } 400 \text { H.P., per model. } \\
\text { (D2) - Conventional engines with over } 400 \text { H.P., per model. } \\
\text { (D3) - Turbine engines, per model. }\end{array}$ \\
\hline $\begin{array}{l}\text { Pattern } \\
\text { Maintenance, } \\
\text { modifications, and } \\
\text { aircraft propellers and } \\
\text { rotors repair. }\end{array}$ & $\begin{array}{l}\text { (E1) - Wood propellers, metal or composite, fixed pitch, per model. } \\
\text { (E2) - All other propellers, per model. } \\
\text { (E3) - Helicopters rotors, per model. }\end{array}$ \\
\hline $\begin{array}{l}\text { Pattern } F \quad- \\
\text { Maintenance and } \\
\text { aircraft equipment } \\
\text { repair. }\end{array}$ & $\begin{array}{l}\text { (F1) - Communications and navigation aircraft equipment, per model } \\
\text { (F2) - Aircraft instruments, per instrument type. } \\
\text { (F3) - Mechanical accessories, aircraft electrical and electronics, per } \\
\text { accessory model. }\end{array}$ \\
\hline $\begin{array}{l}\text { Pattern H - } \\
\text { Specialized services. }\end{array}$ & $\begin{array}{l}\text { (H) - Single Class - Specific activities for the maintenance implementation } \\
\text { that aeronautical authority upheld, per type service (e.g., nondestructive } \\
\text { testing, floats, emergency equipment, rotor shovels, screen coating). }\end{array}$ \\
\hline
\end{tabular}

Source: Brazil (2005).

\section{PROCESS OF TECHNICAL CAPABILITY CLUSTERING}

The number of combined certifications (companies that possesses two certifications simultaneously) regarding to different classes and patterns of certifications are shown in Table 2. Diagonally it is possible to note the absolute total of certifications for each class and pattern and also the number of companies certified in more than one class and pattern of certificate are shown combining lines and columns.

Therefore, data in Table 2 demonstrate that, from the total of 279 certificates issued to the C2 type, 115 were issued for aircraft repair stations that also have 
INDEPENDENT JOURNAL OF MANAGEMENT \& PRODUCTION (IJM\&P)

http://www.ijmp.jor.br

V. 4, n. 2, July - September 2013.

ISSN: 2236-269X

DOI: 10.14807/ijmp.v4i2.101

certifications D1 type. In the same way, from the total of 106 certifications issued for the F2 type, 100 were issued for aircraft repair stations that also have certifications F3 type.

Table 2: Combined certifications matrix

\begin{tabular}{|c|c|c|c|c|c|c|c|c|c|c|c|c|c|c|}
\hline & C1 & $\mathrm{C} 2$ & C3 & C4 & D1 & D2 & D3 & E1 & E2 & E3 & F1 & F2 & F3 & H \\
\hline C1 & 86 & 83 & 1 & 5 & 55 & 7 & 6 & 12 & 13 & 1 & 6 & 3 & 31 & 19 \\
\hline C2 & 83 & 279 & 6 & 75 & 115 & 9 & 127 & 19 & 42 & 15 & 44 & 37 & 123 & 77 \\
\hline C3 & 1 & 6 & 9 & 1 & 1 & 0 & 7 & 0 & 1 & 2 & 3 & 3 & 7 & 6 \\
\hline C4 & 5 & 75 & 1 & 209 & 13 & 0 & 139 & 6 & 22 & 10 & 59 & 53 & 153 & 129 \\
\hline D1 & 55 & 115 & 1 & 13 & 134 & 8 & 38 & 20 & 28 & 6 & 8 & 7 & 75 & 37 \\
\hline D2 & 7 & 9 & 0 & 0 & 8 & 10 & 1 & 1 & 2 & 0 & 1 & 0 & 1 & 0 \\
\hline D3 & 6 & 127 & 7 & 139 & 38 & 1 & 244 & 9 & 38 & 15 & 71 & 66 & 179 & 135 \\
\hline E1 & 12 & 19 & 0 & 6 & 20 & 1 & 9 & 30 & 29 & 1 & 3 & 2 & 25 & 17 \\
\hline E2 & 13 & 42 & 1 & 22 & 28 & 2 & 38 & 29 & 60 & 5 & 18 & 16 & 49 & 34 \\
\hline E3 & 1 & 15 & 2 & 10 & 6 & 0 & 15 & 1 & 5 & 15 & 8 & 8 & 12 & 9 \\
\hline F1 & 6 & 44 & 3 & 59 & 8 & 1 & 71 & 3 & 18 & 8 & 112 & 98 & 104 & 70 \\
\hline F2 & 3 & 37 & 3 & 53 & 7 & 0 & 66 & 2 & 16 & 8 & 98 & 106 & 100 & 62 \\
\hline F3 & 31 & 123 & 7 & 153 & 75 & 1 & 179 & 25 & 49 & 12 & 104 & 100 & 346 & 202 \\
\hline H & 19 & 77 & 6 & 129 & 37 & 0 & 135 & 17 & 34 & 9 & 70 & 62 & 202 & 260 \\
\hline
\end{tabular}

However, according to Fávaro et al. (2009), an important aspect to be considered in a cluster analysis is the use of variables with different measures, which can lead to a distortion of the group structure. This influence of variables different magnitudes can be solved with variables standardization.

Thus, the data presented in Table 2 were standardized by the maximum amplitude method, which attributes to each variable the maximum value of 1 , and is calculated by dividing the value of each variable by the maximum value of the class analyzed. shows those standardized values of the variables obtained from Table 2.

Table 3: Standardized Combined Certifications Matrix.

\begin{tabular}{|c|c|c|c|c|c|c|c|c|c|c|c|c|c|c|}
\hline & C1 & C2 & C3 & C4 & D1 & D2 & D3 & E1 & E2 & E3 & F1 & F2 & F3 & $\mathrm{H}$ \\
\hline C1 & 1,000 & 0,965 & 0,012 & 0,058 & 0,640 & 0,081 & 0,070 & 0,140 & 0,151 & 0,012 & 0,070 & 0,035 & 0,360 & 0,221 \\
\hline C2 & 0,297 & 1,000 & 0,022 & 0,269 & 0,412 & 0,032 & 0,455 & 0,068 & 0,151 & 0,054 & 0,158 & 0,133 & 0,441 & 0,276 \\
\hline C3 & 0,111 & 0,667 & 1,000 & 0,111 & 0,111 & 0,000 & 0,778 & 0,000 & 0,111 & 0,222 & 0,333 & 0,333 & 0,778 & 0,667 \\
\hline C4 & 0,024 & 0,359 & 0,005 & 1,000 & 0,062 & 0,000 & 0,665 & 0,029 & 0,105 & 0,048 & 0,282 & 0,254 & 0,732 & 0,617 \\
\hline D1 & 0,410 & 0,858 & 0,007 & 0,097 & 1,000 & 0,060 & 0,284 & 0,149 & 0,209 & 0,045 & 0,060 & 0,052 & 0,560 & 0,276 \\
\hline D2 & 0,700 & 0,900 & 0,000 & 0,000 & 0,800 & 1,000 & 0,100 & 0,100 & 0,200 & 0,000 & 0,100 & 0,000 & 0,100 & 0,000 \\
\hline D3 & 0,025 & 0,520 & 0,029 & 0,570 & 0,156 & 0,004 & 1,000 & 0,037 & 0,156 & 0,061 & 0,291 & 0,270 & 0,734 & 0,553 \\
\hline E1 & 0,400 & 0,633 & 0,000 & 0,200 & 0,667 & 0,033 & 0,300 & 1,000 & 0,967 & 0,033 & 0,100 & 0,067 & 0,833 & 0,567 \\
\hline E2 & 0,217 & 0,700 & 0,017 & 0,367 & 0,467 & 0,033 & 0,633 & 0,483 & 1,000 & 0,083 & 0,300 & 0,267 & 0,817 & 0,567 \\
\hline E3 & 0,067 & 1,000 & 0,133 & 0,667 & 0,400 & 0,000 & 1,000 & 0,067 & 0,333 & 1,000 & 0,533 & 0,533 & 0,800 & 0,600 \\
\hline F1 & 0,054 & 0,393 & 0,027 & 0,527 & 0,071 & 0,009 & 0,634 & 0,027 & 0,161 & 0,071 & 1,000 & 0,875 & 0,929 & 0,625 \\
\hline F2 & 0,028 & 0,349 & 0,028 & 0,500 & 0,066 & 0,000 & 0,623 & 0,019 & 0,151 & 0,075 & 0,925 & 1,000 & 0,943 & 0,585 \\
\hline F3 & 0,090 & 0,355 & 0,020 & 0,442 & 0,217 & 0,003 & 0,517 & 0,072 & 0,142 & 0,035 & 0,301 & 0,289 & 1,000 & 0,584 \\
\hline H & 0,073 & 0,296 & 0,023 & 0,496 & 0,142 & 0,000 & 0,519 & 0,065 & 0,131 & 0,035 & 0,269 & 0,238 & 0,777 & 1,000 \\
\hline
\end{tabular}

In Table 3, it is possible to verify the different similarity degrees between different classes of certification. The closer the values are to 1 , the higher is the level of composed certifications. In order to a more accurate analysis it was applied generating clusters method.

\subsection{Generating Clusters Method}


DOI: 10.14807/ijmp.v4i2.101

According to Wedel and Kamakura (2000), there are three major methods of generating clusters: no overlapping methods, overlapping methods and the fuzzy set method. In the case of no overlapping methods, an entity belongs to one and one only, cluster; in overlapping methods, an entity may belong to more than one cluster; and in the case of fuzzy method, entities belong partially to more than one cluster. In this work only no overlapping methods were applied.

There are two different methods of generating no overlapping clusters commonly distinguished: hierarchical methods and nonhierarchical. Hierarchical methods do not identify a set of clusters directly. These methods identify hierarchical relationships between objects by using some measure of similarity between them. Some examples of hierarchical methods are the single-link, complete-link, groupaverage, centroid clustering and Ward's method. Nonhierarchical methods derive clusters from the sample directly from a data matrix, typically by optimizing an objective function. The methods k-means and k-harmonic means are examples of non-hierarchical methods in which a quadratic function is minimized.

Regarding fuzzy method, two different methods of generating clusters can be distinguished: procedures based on fuzzy set theory and mixture procedures. Mixture procedures assume segments are no overlapping, but due to the limited information presented in data, subjects are assigned to segments with uncertainty, reflected in probabilities of each cluster, while the fuzzy procedures assume that consumers have partial membership in several segments (WEDEL; KAMAKURA, 2000).

A classification scheme per clustering method elaborated by Wedel and Kamakura (2000) is presented in Figure 1.

In this study it was chosen the hierarchical method of generating clusters, since, according to Webb (2002), this is the most commonly used method to summarize data, which is the goal of this study. 
DOI: 10.14807/ijmp.v4i2.101

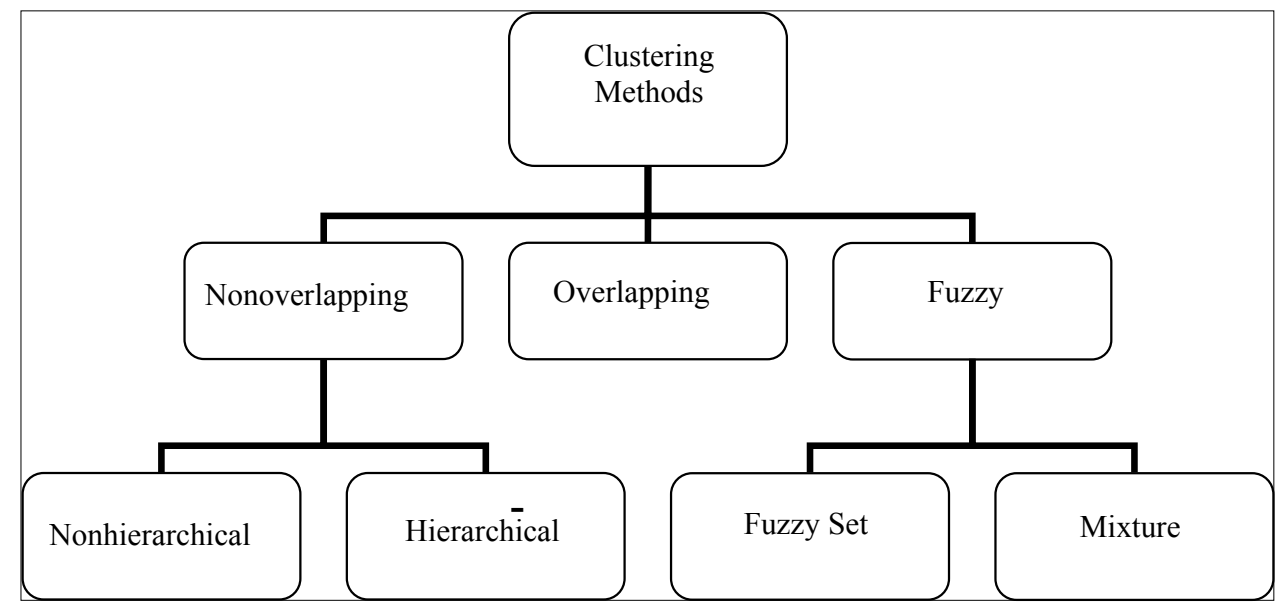

Figure 1: Classification of Clustering Methods

Source: Wedel and Kamakura (2000)

\subsection{Clustering Hierarchical Methods}

Clustering hierarchical methods are widely applied in different knowledge areas. Hierarchical classifications typically result in a dendrogram, a tree structure that represents the hierarchical relations among all objects being clustered. According to Wedel and Kamakura (2000), clusters themselves are not derived directly by the hierarchical methods, and a researcher seeking a solution with a certain number of clusters will need to decide how to arrive at those clusters form the tree representation produced.

Hierarchical cluster algorithms operate on the basis of the relative dissimilarity of the objects being clustered. A variety of similarity, dissimilarity and distance measures can be used in hierarchical cluster analysis. Those similarity measures assess the strength of the relationship between the objects clustered and are derived from the variables measured on the objects. According to Wedel and Kamakura (2000), the type of dissimilarity measure used must be chosen by the researcher, and will depend on the kind of problem features. The most commonly used dissimilarity measures for numeric data are presented in Table 4 .

Agglomerative hierarchical algorithms are the most commonly used hierarchical methods and they work in the following way (MINGOTI; LIMA, 2006): in the first stage each of the $\mathrm{N}$ objects to be clustered is considered as a unique cluster. The objects are then, compared among themselves by using a measure of distance such as Euclidean, for example. The two clusters with smaller distance are joined. The same procedure is repeated over and over again until the desirable number of clusters is achieved. Only two clusters can be joined in each stage and they cannot 
INDEPENDENT JOURNAL OF MANAGEMENT \& PRODUCTION (IJM\&P)

http://www.ijmp.jor.br

v. 4, n. 2, July - September 2013.

ISSN: 2236-269X

DOI: 10.14807/ijmp.v4i2.101

be separated after they are joined. A linkage method is used to compare the clusters in each stage and also to decide which of them should be combined.

Table 4 - Most commonly used dissimilarity measures

\begin{tabular}{ll}
\hline Measures & Formula \\
\hline Euclidean Distance & $\left(\sum_{k}\left(y_{n k}-y_{m k}\right)^{2}\right)^{1 / 2}$ \\
Correlation Coefficient & $1-\sum_{k}\left(y_{n k}-y_{n}\right)\left(y_{m k}-y_{m}\right) / \sigma_{n} \sigma_{m}$ \\
City Block Distance & $\sum_{k}\left|y_{n k}-y_{m k}\right|$ \\
Mahalanobis Distance & $\left(y_{n}-y_{m}\right)^{\prime} \sum^{-1}\left(y_{n}-y_{m}\right)$ \\
Minkowski Distance & $\left(\sum_{k} w_{k}\left(y_{n k}-y_{m k}\right)^{r}\right)^{1 / r}$ \\
Angular Distance & $\sum_{k} y_{n k} y_{m k} /\left(\sum_{k} y_{n k}^{2} y_{m k}^{2}\right)^{1 / 2}$ \\
Canberra Distance & $\sum_{k} \mid y_{n k}-y_{m k} /\left(y_{n k}+y_{m k}\right)$ \\
\hline
\end{tabular}

Source: Wedel and Kamakura (2000)

The Table 5 presents clusters dissimilarity definitions for some of the most commonly used methods. According to Johnson and Wichern (2002) apud Mingoti and Lima (2006), Single Linkage, Complete Linkage and Average linkage methods, can be applied in quantitative or qualitative variables, Centroid and Ward's methods are only appropriate for quantitative variables.

Table 5 - Most common used cluster dissimilarity relation

\begin{tabular}{ll}
\hline Algorithm & Recurrence relation of distance \\
\hline Single Linkage & Shortest distance between two cluster members \\
Complete Linkage & Greatest distance between two cluster members \\
Average Linkage & Average distance between two cluster members \\
Centroid Linkage & Distance between segment averages of variables \\
Ward & Minimum increase in total sum of squares \\
\hline
\end{tabular}

Source: Johnson and Wichern (2002) apud Mingoti and Lima (2006)

\subsection{Certifications Cluster}


INDEPENDENT JOURNAL OF MANAGEMENT \& PRODUCTION (IJM\&P)

http://www.ijmp.jor.br

v. 4, n. 2, July - September 2013.

ISSN: 2236-269X

DOI: 10.14807/ijmp.v4i2.101

In this study, data were classified by using information from the standardized matrix shown in Table 3. To perform the hierarchical analysis of clusters generation, it was chosen Euclidean distance with subsequent application of the Ward method, due to the quantitative analysis.

The Figure 2 presents the aeronautical maintenance homologation certificates cluster dendrogram by pattern.

Figure 2 - Certifications cluster dendrogram.

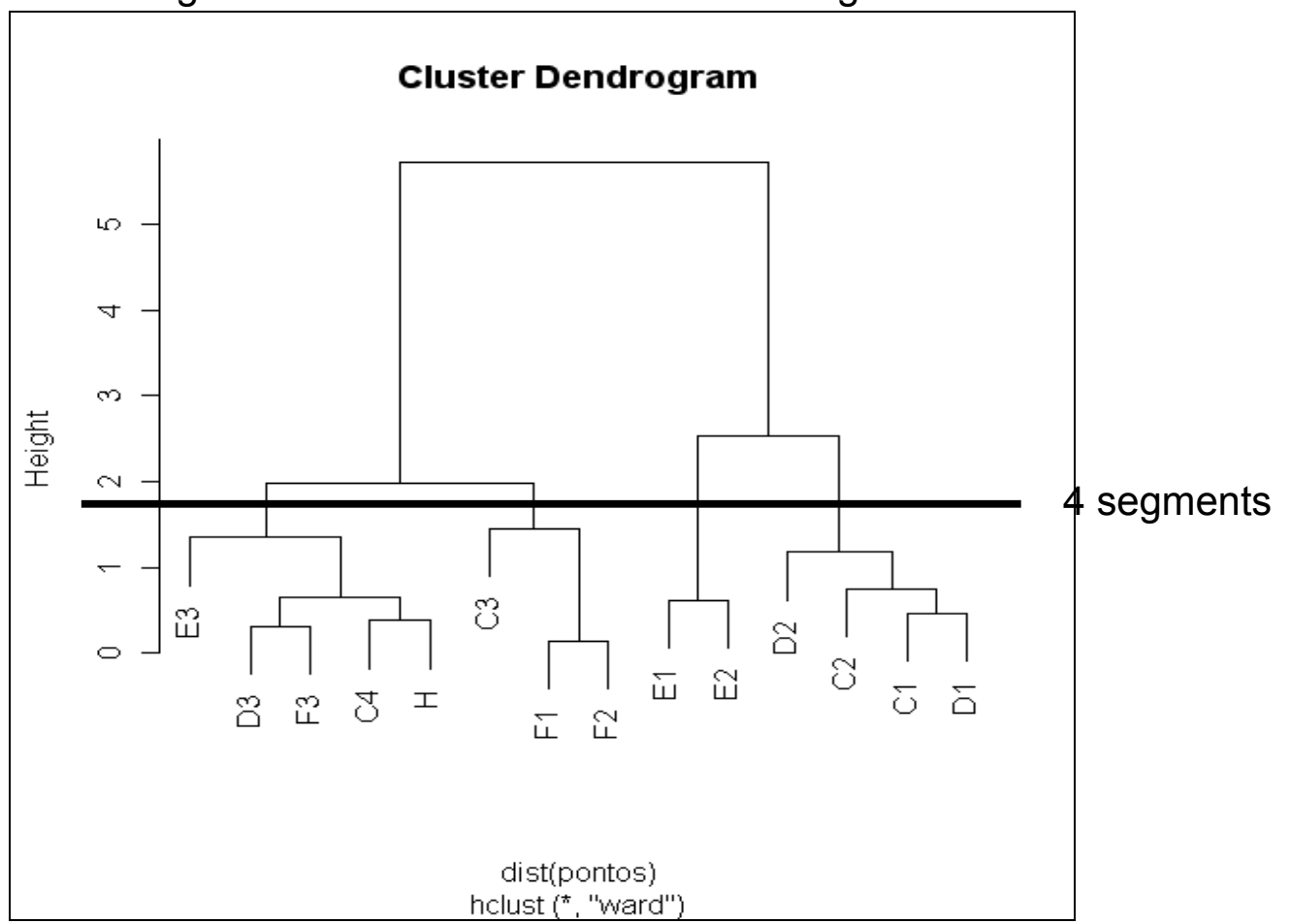

When the clusters are observed, it can be verified that in the first cluster, from left to right, the E3 pattern (Helicopter Rotors) is in an isolated branch, situation justified by its specificity.

Still in the first cluster, the "D3" patterns (turbine engines) and "F3" (aircraft mechanical, electrical and electronic accessories) are in the same branch, which is also justified as the turbine engines have a large quantity of accessories that also need specific maintenance. The "D3-F3" pattern branches are associated to the "C4$\mathrm{H}$ " pattern branches (" $\mathrm{C} 4$ " related to metallic structure aircrafts, with maximum takeoff approved weight above $5670 \mathrm{~kg}$ (airplane) or $2730 \mathrm{~kg}$ (helicopters) and "H" being related to specific maintenance in activities execution). This makes sense as larger aircrafts are the ones that commonly have turbine engines. 
DOI: 10.14807/ijmp.v4i2.101

In the second cluster, it can be observed that the "C 3 " pattern (combined structure aircraft, with maximum takeoff approved weight above $5670 \mathrm{~kg}$ (airplane) or $2730 \mathrm{~kg}$ (helicopters)) are in a specific branch, clustered, however, with "F1 and F2" patterns (aircraft communication/navigation equipment's and aircraft instruments, respectively). Taking into account that combined structure aircraft are, normally, more modern and also that more modern aircraft are the ones which have more communication/navigation equipment's and instruments, that agglomeration in the second cluster is coherent.

In the third cluster, it is possible to identify a certification cluster for propellers maintenance certifications ("E1 and E2"), which is justifiable by it.

In the fourth cluster, are concentrated companies certifications that perform maintenance in conventional engines, "D1 and D2" pattern, along with "C1 and C2" patterns, associated to modifications and repairs of smaller aircrafts cells, which consequently use, generally, conventional engines.

This analysis, from the dendrogram, enabled to find out that the aeronautical maintenance companies are trying to certify themselves into groups and maintenance classes patterns that will possibly increase their services scope for certain types of aircraft. Therefore, we can say that the training of the workforce must also follow the same structure as identified in the dendrogram. However, the high degree of specialization of technical training can make it difficult for the same technician has different capabilities, generating costs in hiring. These issues may be targeted for future research.

\section{CONCLUSION}

Aircraft maintenance activities are an essential part of the continued airworthiness, aiming to provide, both, in civilian and military areas, the total service condition for the aircraft at the time that an operator request, with the expected quality and minimal cost. This service is extremely important to support the air transportation in countries like Brazil, which are characterized by having a large territory with strong civilian and military air traffic, linking the various regions of the country.

It is observed that, depending on the complexity and the advancement of the technologies used in aircraft, technical training required for the aircraft maintenance 
DOI: 10.14807/ijmp.v4i2.101

is too qualified, requiring that companies have on their staffs, human resources qualified to maintenance activities they intend to accomplish. Finding this qualified workforce cannot be so easy, since hiring skilled labor is a problem that affects not only the aviation industry but also other sectors those necessities a workforce with a similar level of technical skills.

This paper has presented a process of technical training clustering in aircraft maintenance industry that offers a useful overview of the skills sector. More than that, the clustering process implies that the process of qualification of the workforce can be achieved by combining the different skills identified in each cluster. The clustering process used in this work follows a basic methodology of clustering, however the insights arising from the clustering process is unique to the understanding of the characteristics of technical training in a particular sector of the economy. From this process of clustering is possible to question the way it gives the training of the workforce for the sector.

Finally, it is possible to infer that the clustering process can be useful across different sectors, given that there are other sectors that have similar characteristics to the aviation industry by using equipment complex and technologically advanced. As a recommendation, we suggest the application of this clustering process in other industries.

\section{REFERENCES}

ANAC (2010). Empresa de Manutenção. Relação de Empresas de Manutenção Aeronáutica Certificadas. Available: <http://www.anac.gov.br>. Access: 19 may, 2010.

BRAZIL (2003a) Comando da Aeronáutica. RBHA 121: requisitos operacionais: operações domésticas, de bandeira e suplementares. Brasília-DF, 2003.

BRAZIL (2003b) Comando da Aeronáutica. RBHA 121: requisitos operacionais: operações complementares e por demanda. Brasília-DF, 2003.

BRAZIL (2005) Comando da Aeronáutica. RBHA 145: empresas de manutenção de aeronaves. Brasília-DF, 2005.

CHANG, Y. H.; WANG, Y. C. (2010). Significant human risk factors in aircraft maintenance technicians. Safety Science, v. 48, n. 1, p. 54-62.

DE BRUECKER, P.; VAN DEN BERGH, J.; BELIEN, J.; DEMEULEMEESTER, E. (2012). A model enhancement heuristic for building robust aircraft maintenance personnel rosters under stochastic constraints. status: published. Proceedings of the 1st International Conference on Aircraft Operations Management (AOM) v. 1 p. 6063. 
INDEPENDENT JOURNAL OF MANAGEMENT \& PRODUCTION (IJM\&P)

http://www.ijmp.jor.br

v. 4, n. 2, July - September 2013.

ISSN: 2236-269X

DOI: 10.14807/ijmp.v4i2.101

DURAND, J. M. (2008) Aircraft Maintenance Organizational Structure Changes: An Antecedent Model. Dissertation (Master in Engineering). Ohio: AFIT.

EURESPACE. (2003) The human factors in aeronautical maintenance study. Ref.: NT/1354A/03/021 Rev.B 07 outubro.

FÁVARO, L. P. et al. (2009) Análise de dados: modelagem multivariada para tomada de decisões. Rio de Janeiro: Elsevier.

JACOB, C.; DUBOIS, D.; CARDOSO, J.; CEBERIO, M.; KREINOVICH, V. (2011). Estimating probability of failure of a complex system based on partial information about subsystems and components, with potential applications to aircraft maintenance. Departmental Technical Reports (CS). Paper 615. http://digitalcommons.utep.edu/cs_techrep/615.

KNOTTS, R. M. H. (1999) Civil aircraft maintenance and support: fault diagnosis from a business perspective. Journal of Quality in Maintenance Engineering, v. 5, n. 4, p. 335-347.

MACHADO, M. C.; URBINA, L. M.; ANDRADE, D.; LUCHT, R. R. (2009) Avaliação de empresas de manutenção aeronáutica Anais do 2009 SBEAE. Brazilian Symposium on Aerospace Enginneering \& Applications, São José dos Campos.

MINGOTI, S. A.; LIMA, J. O. (2006) Comparing SOM neural network with Fuzzy cmeans, K-means and traditional hierarchical clustering algorithms. European Journal of Operational Research, v. 174, n. 3, p. 1742-1759.

MISHRA, R. P.; ANAND, G.; KODALI, R. (2006) Development of a framework for world-class maintenance systems. Journal of Advanced Manufacturing Systems, v. 5, n. 2, p. 141-165.

MOAYED, F. A.; SHELL, R. L. (2009) Comparison and evaluation of maintenance operations in lean versus non-lean production systems. Journal of Quality in Maintenance Engineering, v. 15, n. 3, p. 285-296.

MUCHIRI, P.; PINTELON, L.; GELDERS, L.; MARTIN, H. (2011). Development of maintenance function performance measurement framework and indicators. International Journal of Production Economics, v. 131, n. 1, p. 295-302.

NIU, G.; YANG, B. S.; PECHT, M. (2010). Development of an optimized conditionbased maintenance system by data fusion and reliability-centered maintenance. Reliability Engineering \& System Safety, v. 95, n. 7, p. 786-796.

PAPAKOSTAS, N.; PAPACHATZAKIS, P.; XANTHAKIS, V.; MOURTZIS, D.; CHRYSSOLOURIS, G. (2010) An approach to operational aircraft maintenance planning. Decision Support Systems, v. 48, n. 4, p. 604-612.

PHILLIPS, P.; DISTON, D.; STARR, A.; PAYNE, J.; PANDYA, S. (2010). A review on the optimisation of aircraft maintenance with application to landing gears. In Engineering Asset Lifecycle Management (p. 68-76). Springer London.

RODRIGUES, L. R.; GOMES, J. P. P.; DE OLIVEIRA BIZARRIA, C.; GALVAO, R.; YONEYAMA, T.(2010), Using prognostic system and decision analysis techniques in aircraft maintenance cost-benefit models. In: AEROSPACE CONFERENCE, 2010 IEEE , v. 1, n. 7, p. 6-13.

SAMARANAYAKE, P. (2006) Current practices and problem areas in aircraft maintenance planning and scheduling: interfaced/integrated system perspective. In: 
DOI: 10.14807/ijmp.v4i2.101

INDUSTRIAL ENGINEERING AND MANAGEMENT SYSTEMS, Proceedings of the 7th asia-pacific conference in bangkok, UWS, Sidney, p. 2245-2256. Thailand: 2006.

SAMARANAYAKE, P., et al. (2007), Reliability improvements in aircraft maintenance planning and scheduling under uncertainty, In: QUALITY AND RELIABILITY Proceedings of the $\mathbf{V}$ International Conference in Chiang Mai, UWS, Sidney, p. 49-55. Thailand: 2007.

SHERWIN, D. (2000), A review of overall models for maintenance management. Journal of Quality in Maintenance Engineering, v. 6, n. 3, p. 138-164.

SORO, I. W.; NOURELFATH, M.; Aït-KADI, D. (2010). Performance evaluation of multi-state degraded systems with minimal repairs and imperfect preventive maintenance. Reliability Engineering \& System Safety, v. 95, n. 2, p. 65-69.

VILELA, J. A. B. M., et al., (2010) Manutenção em aeronaves: fator contribuinte para a Segurança de Aviação, Revista Conexão SIPAER, v. 1, n. 2, p. 85-99.

VOSS, C.; TSIKRIKTSIS, N.; FROHLICH, M. (2002) Case Research in Operations Management, International Journal of Operations and Production Management, v. 22, n. 2, p. 195-219.

WARD, M.; McDONALD, N.; MORRISON, R.; GAYNOR, D.; NUGENT, T. (2010). A performance improvement case study in aircraft maintenance and its implications for hazard identification. Ergonomics, v. 53, n. 2, p. 247-267.

WEBB, A. (2002) Statistical pattern recognition. New York: John Wiley \& Sons.

WEDEL, M. and KAMAKURA, W. A. (2000) Market segmentation: Conceptual and methodological foundations. Massachusetts: Hingham Kluwer Academic. 